\title{
Illegal Immigration in USA: Policy and Demand Dilemma
}

\author{
Mahmuda Khatun ${ }^{*}$ \\ Associate Professor, Department of Sociology \\ University of Dhaka, Bangladesh \\ Sharmeen Ahmed \\ School of Liberal Arts and Social Sciences \\ Independent University of Bangladesh, Dhaka, Bangladesh
}

\begin{abstract}
Economic superpower USA receives a large number of illegal immigration each year. The main dilemma is USA needs illegal immigration for continuing activities of the country, but a section of citizen does not share liberal views. They blame that illegal immigrants are curtailing many of their facilities which they used to enjoy. As a result, four major categories of policies have been implemented with anti-immigration sentiments. Interestingly, the policies that have taken to reduce flow of illegal immigration are not meant to stop illegal immigration. This paper tries understands public and private interest dilemma in the context of immigration policies starting from 1790. Moreover, a critical examination of the problem raised a serious question whether US has ever took a serious effort to stop illegal immigration. Do polices playing hide and seek with illegal immigrants?
\end{abstract}

Key words: Immigration, immigration policies, illegal immigrants

\section{INTRODUCTION}

Since the beginning of human history, men were essentially nomadic. Scarcity of animal protein and plants pushed them to move from one place to another. Even after introduction of permanent agricultural system, migrating locally never stopped. With new scientific discoveries, especially invention of penicillin and medical technologies, a gradual decline in mortality was on the way. For the first time in history, population growth curve reached its acme. This unprecedented growth stimulated migration in a larger scale. From this point on, mass migration became the key cause of population redistribution around the globe. Further impetus came from the industrial and transportation revolution (Tanton, 1996). With the concern of national security and economic development, countries implement policies to restrict migration from one country to another. Here comes the concept of illegal migration, which has far reaching consequences. USA is one of the best examples where illegal immigration is a sensitive issue affecting its economic and social set up.

Illegal immigration is largely an economic process that shifts poor labor class from their country of origin to relatively wealthy nations. Two factors such as factors of expulsion (hardship caused by economic, social, and political reasons at the place of origin) and factors of attraction (economic advantages at the place of destination) worked as the prime determinants of migration. This theoretical orientation which is known as "push-pull model" failed to capture differential based on collectivities and differential based on * The material presented by the author does not necessarily portray the viewpoint of the editors and the management of the Institute of Business \& Technology (BIZTEK) or University of Dhaka, Bangladesh \& School of Liberal Arts and Social Sciences Independent University of Bangladesh, Dhaka, Bangladesh.

*Mahmuda Khatun : mahmuda1996@yahoo.com

*Sharmeen Ahmed : disha@iub.edu.bd

C JMSS is published by the Institute of Business and Technology (BIZTEK). Main Ibrahim Hydri Road, Korangi Creek, Karachi-75190, Pakistan. 
individuals. Moreover, macro and micro-structural determinants of migration were absent from the model, let alone the issues of illegal immigration.

At the macro level, wage gap which exist among countries along with economic gap among different social classes forced a large number of people to migrate from the place of origin. Since more or less all rich countries once established their colonies around the globe, slaves were exported from the colony to colonial countries. They formed the early ethnic minorities in those countries. These countries not only contain a vast majority of migrants, consequently they create an internal imbalance in terms of economic and political power. At the micro-level, people continued to migrate because they developed networks. Because of these networks, migrants find less difficulty in settling down and finding jobs at the places of destination. Characteristically, this behavior is social in nature. Obviously, having ties with these networks can explain people's motivation to migrate and flow of migration towards place of destination (Portes, 1991).

Contrary to the popular theoretical approaches is the Marxist economists' view which asserts that rich states are actually in need of migrants to fully utilize their land or capital. They further argue that rational calculation on the part of migrants is not the root cause of migration rather analyzing economic, social and political institutions is more important to explain/understand the situation. Moreover, labor migration is necessary in order to expand capitalist system further. Developed countries need them. Developing countries are also trying hard to cope with extreme economic and social poverty by sending migrants (Clark, 1986). Comparative disadvantages which exist at home, increasing needs developed countries have and social networks - all these factors can explain illegal immigration essentially. Dynamics may take different shapes but root causes will remain same. For analyzing the real dynamics of illegal immigration in USA, we have to look back.

Mostly cheap fertile land at the place of destination and extreme hardship at the home front with unprecedented population growth forced people to migrate to the United States, Canada, South Africa, and New Zealand. A lion share of international migrants had selected United States as their dream land (Boyle et al., 1998). During 1950's, on an average US received 125 migrants per hour, which means 3000 a day and more than one million per year. Only 30 percent of these migrants left USA forever but the rest 70 percent became permanent resident of the country (Tyler, 1956). These early migrants and their successive generations help building the country that we see today.

More than 300 years, USA maintained an open door policy. Due to huge influx of international migration, "welcome whoever comes in" policy halted for the first time. Tougher immigration policies were implemented. In 1965, migration policies become flexible again. Third world countries are the major sources of illegal immigrants (Miller, 1996). Although US government keeps good relations with her neighbors, still it wants to tighten border due to increased threats to national security. Interestingly, tighten border does not imply that a migrant is not welcome. Virtually, society in general and work place in particular remain wide open for illegal migrants (Andreas, 2000). Even after introducing rules and regulations, still a large number of people managed to get in USA. At this point, the two fundamental questions remain unanswered - To what extent the United States is willing to stop illegal immigration? Are immigration policies compatible enough to stop illegal immigration? These questions will be the key focal points of this paper.

\section{ILLEGAL IMMIGRANTS: UNDOCUMENTED OR VISA ABUSERS}

Voluntary movement on the part of a person essentially defines him as a migrant. When persons move from their place of origin to somewhere else for security purpose or for religious reasons, they are identified as refugees. Usually, these are the two common routes of immigration. The rest is often considered as illegal migrants. However, a huge debate rose around the definition of illegal immigrants (Miller, 1996). Less negative definition which has been used is "undocumented" migrants. In some instances, word "alien" is used 
to describe illegal immigrants. Some still rather choose the phrase "migrants" as these people thought to come in USA temporarily. In 1985, Immigration and Naturalization Service (INS) defines illegal migrants by including several characteristics, such as- a) a non-citizen presents in the USA b) who entered without legal permission c) did not regularize his or her situation and d) violated terms and conditions of entry regulation (Bouvier and Gardner, 1986). However, US Census Bureau categorized illegal immigrants into two groups: settlers (come to US temporarily) and sojourners (cross the border daily).

US researchers so far identified two types of illegal immigrants (Briggs, 1984). One group comes without legal permission. Sometimes they move alone, sometimes they move in a group. Swimming, sailing, rowing, driving, climbing or walking are the popular forms of crossing the borders. Legally, they entered US without inspection, according to INS. The other group entered in USA with legal paper works through an established port of entry but become illegal after violating rules associated with their visas. Some of them decided not to take care of their visas. There are two reasons of becoming illegal migrants from legal immigrants: one is, visa is refused by the consular office and the other is they knew ahead of time they will not get visa again. This is also possible that these migrants entered USA with fake documents at the first place. They feared that they got caught if their papers have been reviewed. These migrants might get involved with labor market, which is apparently makes them illegal as they are not allowed to do so. Popularly they are called out as "visa abusers" (Briggs, 1984).

\section{TRENDS OF ILLEGAL IMMIGRATION IN THE UNITED STATES}

The very first question pops in one's mind about number of illegal immigrants present in USA. Bouvier and Gardner (1986) once mentioned that they just do not know. Obviously, this figure needs to come out as it is one of the substantial causes of population change. Back in 80s, one-fifth of average annual immigrants were illegal (Smith and Edmonston, 1997). INS provided a detail data on number of illegal immigrants based on apprehension data. Operation Wetback, launched by INS and sponsored by Eisenhower Administration, found out a total of 1, 248,000 apprehended cases in 1983. Even though this number is lower than actual illegal immigrant present in the country, the rate has been increased since 1964 (Briggs, 1984).

State level data show that around 40 percent of the 5 million immigrants, which means around 2 million; illegal immigrants live in California in October 1996 (Desipio and Garza, 1998). Eighty-three percent of the total illegal immigrants were received by Texas $(700,000)$, New York $(540,000)$ Florida $(350,000)$, Illinois $(290,000)$, New Jersey $(135,000)$ and Arizona $(115,000)$ (Table 3. 1). Except Massachusetts, other states on an average have experienced 3,000 illegal immigrants each year (U.S. Immigration and Naturalization Service, 1997).

Table 3.1

Illegal Immigrant Population by State, October 1996

\begin{tabular}{|l|r|l|r|}
\hline State & Population & State & Population \\
\hline California & $2,000,000$ & Maryland & 44,000 \\
\hline Texas & 700,000 & Michigan & 37,000 \\
\hline New York & 540,000 & Pennsylvania & 37,000 \\
\hline Florida & 350,000 & New Mexico & 37,000 \\
\hline Illinois & 290,000 & Oregon & 33,000 \\
\hline New Jersey & 135,000 & Georgia & 32,000 \\
\hline Arizona & 115,000 & District of Columbia & 30,000 \\
\hline Massachusetts & 85,000 & Connecticut & 29,000 \\
\hline Virginia & 55,000 & Nevada & 24,000 \\
\hline Washington & 52,000 & Other states & 330,000 \\
\hline Colorado & 45,000 & Total & $5,000,000$ \\
\hline
\end{tabular}

Source: U.S. Immigration and Naturalization Service, 1997. 
Neighboring country Mexico has always been placed at the top in sending illegal immigrants to US. Nearly 60 percent of total illegal immigrants hail from Mexico. More specifically, nine Latin American, four Caribbean and four Asian countries were major senders of illegal immigrants (Desipio and Garza, 1998). Mexico, El Salvador, Guatemala, Canada and Haiti ranked the top in sending illegal immigrants. Except Mexico, annual contribution of these countries along with the Bahamas is 6000 to 12000 . The rest send approximately send 30,000 illegal immigrants to the US (U.S. Immigration and Naturalization Service, 1997) (Table 3.2). However, INS data have never been taken as unchallenged. The major criticism is that data might have coverage error as one person may have counted more than once. Reason is simple. Some people may be apprehended more than once. Further, patrol activities mainly operated at the southwestern United States. This implies that Mexicans were the only illegal immigrant present in the country which is not the case. Moreover, since its inception INS has failed to captures visa abusers (Briggs, 1984). But current finger-print system which is in action may have a good chance of catching visa abusers.

Table 3.2

Illegal Immigrant Population by Country, October 1996

\begin{tabular}{|l|c|l|c|}
\hline Country of Origin & Illegal Immigrants & Country of Origin & Illegal Immigrants \\
\hline Mexico & $2,700,000$ & Ecuador & 55,000 \\
\hline El Salvador & 335,000 & Dominican Republic & 50,000 \\
\hline Guatemala & 165,000 & Trinidad and Tobago & 50,000 \\
\hline Canada & 120,000 & Jamaica & 50,000 \\
\hline Haiti & 105,000 & Pakistan & 41,000 \\
\hline Philippines & 95,000 & India & 33,000 \\
\hline Honduras & 90,000 & Dominica & 32,000 \\
\hline Poland & 70,000 & Peru & 30,000 \\
\hline Nicaragua & 70,000 & Korea & 30,000 \\
\hline Bahamas & 70,000 & Other & 744,000 \\
\hline Colombia & 65,000 & All countries & $5,000,000$ \\
\hline
\end{tabular}

Source: U.S. Immigration and Naturalization Service, 1997.

Illegal immigrants of late 60s used to work as agriculture laborers and settled down in rural areas because they knew law enforcement agency was not strong enough to catch them. As time went on, fear of being caught is minimized; they developed confidence to live in urban areas. However, the jobs they receive in urban areas failed to provide them monetary protection. Since employers knew that they were illegal, they offer them minimum wage by violating existing federal and state law. Employers also took advantages of their illegal status. They threat them by mentioning that they will let INS know about their status. In some cases, they literally imprison them and used them simply as slaves. Interestingly, some households of US contain both legal and illegal immigrants (Desipio and Garza, 1998).

\section{DOES USA NEED ILLEGAL IMMIGRANTS: WHOSE PERSPECTIVE IS IT ANYWAY?}

It is frequently heard from Americans that illegal immigrants have always been a problem for the country. Some even suggest the government not to process their cases as this requires extensive paperwork with a huge expense. California, Florida, and Texas are the chosen states where illegal immigrants love to go and stay (Desipio and Garza, 1998). The federal government is criticized vehemently for their failure to protect borders. Local citizens ask federal government to repay their tax money which has been spent for processing illegal immigrants' documents to prove their legal status. Moreover, providing education facilities for immigrants' children, social welfare benefits, emergency medical services, and costs associated with imprisoning illegal immigrants make natives to pay more taxes (Desipio and Garza, 1998). In fact, inherent but not spoken story is that because of illegal 
immigrants natives receive less and less facilities from federal government. They felt threatened by the presence of illegal immigrants.

Californian spent \$1178, whereas a person from New Jersey spent \$232 for illegal immigrants (Smith and Edmonston, 1997). Besides, short term affect, natives also think about long term affect of having illegal immigrants at the state level. Even though Congress is aware that illegal immigrants contribute to country's economy, but with increasing citizens pressure forced them to review the bills whether states should deny educational facilities to illegal immigrants children. This bill has already received support from the House of Representatives but failed to get support from the Senate (Desipio and Garza, 1998). Bottom line is that regardless of their contributions to economy, number of resistance is growing towards illegal immigrants. In order to examine these issues, we have to revisit both economic and non-economic factors.

\subsection{Economic Issue 1: The Primary Labor Market}

Natives often claim that primary labor market is saturated because of illegal immigrants. Competition is enormous for getting a job. Quite contrary to their assumptions, illegal immigrants practically do not serve at the primary labor market. Even though their movement primarily economic in nature but do not have opportunity to have a job at the primary market due to their legal status. Further claim they made that illegal immigrants displacing native workers by taking their jobs. In reality, employers love to hire illegal immigrants, these workers do not think about joining in unions, do not complain about equal employment opportunities, they do not even think about whether employer violated safety rules of workplace, set by state. All they want is to get a job, retain their jobs and earn some money. These work ethics lured employers to hire them, causing workers displacement. However, the dimension of secondary market is quite different from primary labor market.

\subsection{Economic Issue 2: The Secondary Labor Market}

Secondary labor market is the very first place where an illegal immigrant receives a job. In most cases, they take the jobs which nobody wants anymore. These markets do not have much to offer the Americans. Young, housewives, and minority usually serve at the secondary labor market. This situation has been changed between late $70 \mathrm{~s}$ and 80 s, nobody wants these jobs except adolescents who use their earnings from these jobs to buy things they desire, which their parents will not buy for them. Since the adolescents are not enough to saturate the secondary labor market, a huge vacuum was created in sector. Initially, these jobs were not accessible to illegal immigrants. Civil rights movement makes the path for ethnic minority groups. This movement was vocal to provide jobs to ethnic minorities. Moreover, feminist movements make women cautious about their career. Women usually involve in the secondary labor market, but they too do not want these jobs anymore. Nobody is left for taking these jobs. Even though US government can take stern steps to avoid illegal immigration, but not doing so means everyone knew that illegal immigrants are desired to fill the gaps of secondary job markets.

\subsection{Economic Issue 3: Full Employment}

Supply and demand theory states that the more the supply, the more the demand. This essentially boosts up any country's economy. Even though US receives a large number of immigrants each year, but they too contribute by producing more, which makes competitive market even more competitive, consequently consumers buy things at a cheaper price. Some argue that local investors were benefitted because of extra supply of manpower. Since technology is replacing human, illegal immigrants started to look for jobs which might make situation little complicated for natives. 


\subsection{Non-economic Issue: rights vs. humanitarian act}

Illegal immigrants take enormous risks while entering a country with no official documents. Usually they pay money to people who help them crossing the border. While coming to US, some even die due to using unusual way for entering in the US, lack of food and water and so forth. When employers get to know that these are illegal immigrants, they even force them to work longer than usual at gunpoint (Briggs, 1984). They live in a shanty places with no toilet facilities. Since they choose to come to USA, they do not complain to anybody. Since they do not have legal status, they cannot even seek for the legal assistance from proper authorities. Moreover, administration is not willing to file petition in favor of the exploited illegal immigrants; let alone winning the case against the employers. Since they have broken the laws, whom would they complain to? One suggestion is often made to US Government to stop illegal immigration by any means, so that these people do not have to go through such inhuman condition.

With mounting resistance from the natives, US government has decided to curtail many facilities which they used to provide to the illegal immigrants, even though the) US constitution states providing support to these immigrants. Now-a-days, government decided not to provide them any benefit from the social institutions. They do contribute to social security fund but will never be allowed to take benefits out of that fund. Many claim that this is a modern form of slavery (Briggs, 1984).

\section{DO THEY EVER TRY TO STOP ILLEGAL IMMIGRATION?}

Although International Covenant on Civil and Political Rights (Article 12) clearly states that a person can leave his or her country, under international law a sovereign country has a right to protect her border. The question is where these people would go if they were forbidden to go another country but essentially they have to leave their own country. These contradictory laws limit people's mobility (DeLaet, 2000). However, in US largely economic issues determine restricting illegal immigration. Historically, unemployment rate during economic recession forced to come up with more policies. With high unemployment rate, high flow of immigration, along with ideological issues also remain important factors for ever restricted policies (Massey, 1999). From 1600, a total of 49 policies were implemented. This can be categorized into four broad policies, these areopen door policy (1607-1917), restrictive policy (1917-1965), revision of the Immigration Act and modern legislation (Daniels and Graham, 2001).

\subsection{Open Door Policy (1607-1917)}

Immigrants were always welcome from the 1607 to the First World War. Since this is a country of immigrants, their policy is to create space for everyone. Mainly people move to US for economic opportunities that exist in the country, along with vast fertile land. Early flock came from Europe. On 2nd December, 1783 George Washington addressed Irish immigrants mentioning, "The bosom of America is open to receive not only the opulent and respectable stranger but the oppressed and persecuted of all nations and religions; whom we shall welcome to a participation of all our rights and privileges, if by decency and propriety of conduct they appear to merit the enjoyment" (Archive, 2009). This saying essentially endows immigrants to be there and lead the life of a Native American, consequently receive all the facilities that an American receives.

In 1829 , for the first time a law was implemented which clearly stated that immigrants have to pay heavy tax only for entering the country (Daniels and Graham, 2001). Before that no major policies were taken to restrict immigrant coming to US, except a racial policy which gave priorities to white natives. Eighteen years after independence, the Naturalization Act of 1790 recognized only free white persons, no slaves, as citizens of US. Catholic and Protestants fought with each other over the issue of immigration in relation to citizenship. 
However, no immigrants but Chinese faced difficulty immigrating in US. These people worked and still are working for low wages. No wonder, organized labor groups were after Chinese immigrants. Along with this, huge popularity of "Eugenics" which spreads the notion of racial superiority, cultural upsurge of "progressivism" which claims immigrants' inferiority in assimilating the mainstream culture, and the new forms of "the Ku Klux Klan" with hostility towards immigrants created huge barriers for immigrants coming to US.

The very first restricted policy, which was enacted in 1875 , prohibited criminals, prostitutes and disabled coming to US (Daniels and Graham, 2001). This law also prohibited coming coolie laborers and penetration of people, especially Asians who were forced to migrate from their place of origin. Three more immigration laws were also took place in 1882, 1891 and 1903. Chinese Exclusion Act of 1882 enacted as they were being considered as threats to local economy because of their cheap labor. This law limited and stopped migration from China. The law of 1891 had forbidden paupers, polygamists, sick and individuals with moral charges coming to US. Moreover, Gentlemen's Agreement between Japan and US in 1907 confirms no labor immigration to US, but family reunification was permitted. This agreement became known as "Japanese Exclusion Act 1924 (Daniels and Graham, 2001). Along this line, there was a growing concern over the issue of Asian immigration. In 1907, Gentlemen's Agreement had been enacted between Japan and the United States that Japan will not send any laborers towards the United States, except for those who stayed in the US before or wanted to unite with family, children or wife. This agreement became law in 1924, which is later called the Japanese Exclusion Act of 1924 (Daniels and Graham, 2001).

\subsection{Restrictive Policy (1917-1965)}

The first restrictive policy began in 1910 . Without passing the 'literacy test' immigrants were refused to enter into USA. Even after President Wilson vetoed the bill, literacy test was required. Right after World War I, streams of immigrants who went to USA faced strong opposition from labor organization as they were scared of further decline in wage rate. Due to increased opposition from public, the 1921 Quota Act determined that only three percent foreign-born population will be welcomed based on the proportion of immigrants currently present at the country(Miller, 1996). Immigration Act 1924 further reduced this percentage into two percent and for the first time border patrol system was introduced. After World War II, the Immigration and Naturalization Act of 1952 introduced preference system with national origin percentage system. Keeping refugees and displaced persons in mind, the Displaced Persons Act was taken to rehabilitate them. Refugee Relief Act of 1953 introduced to meet the needs of politically displaced people (Miller, 1996).

\subsection{Revision of the Immigration Act, 1965}

Before 1965, there has been no sympathy for immigrants on the part of politicians. During 1950 s, for the first time they gave a thought to change 1924 immigration law. Inspired by J.F. Kennedy, the 1924 act took a new shape, which changed the national origin system known as Immigration Act of 1965. The unique characteristic of the law was to modify no quota for Asians. However, this change was really needed for US economy. Southwest States were in need of agricultural laborers, Mexico failed to send them due to quota system. Moreover, skilled professional were also welcomed through this act. Philippines, Korea, Iran, India, and Thailand sent as many doctors as they could during this period because US could not find adequate number of doctors from Canada and European countries. This law also encouraged immigrants to bring their families (Miller, 1996).

\subsection{Modern Legislation}

More or less Immigration Act of 1965 promoted all sorts of illegal immigration. Congress revaluated the act and made possible modifications. Congress laid out a specific guideline 
for refugees. As a result two more new laws were implemented: one is Immigration Reform and Control Act, 1986 and the other is the Immigration Act, 1991. The first one limited illegal immigration but provided legal papers to 3 million illegal immigrants who already entered US as illegal immigrants. Even this act tried to calm down citizens who were hostile towards immigrants, President Regan signed the bill 6 years after its formulation. The second act was extremely generous to immigrants who fled from their home country due to civil unrest. Numbers of visas were issued to immediate relatives who fled from their country. This act also undertook some provisions to legalize Central American refugees and Filipino Veteran who took part in World War II (Miller, 1996). However, Illegal Immigration Act of 1996 was specially formulated to stop illegal immigration. This is the first of this kind. Two steps were taken to stop illegal immigration. Employers were given authority to check their legal status as immigrants over phone. Border Patrol made stronger by appointing more guards (Smith and Edmonston, 1997).

After 1996, two more immigration laws were implemented. One is Patriot Act 2001 which basically provides latest tools to intercept terrorist attack. The other is Real ID Act of 2005. If a person failed to show de facto id (driver's license with special verification), he or she is supposed to go through special scrutiny system (uwkc.org.

Table 5.1

A Brief History of US Immigration Policy, 1790-2005

\begin{tabular}{|l|l|}
\hline Year & \multicolumn{1}{|c|}{ ACT } \\
\hline 1790 & Naturalization Act of 1790 \\
\hline 1875 & Prohibited criminals, prostitutes, and disabled \\
\hline 1882 & Chinese Exclusion Act \\
\hline 1907 & Gentlemen's Agreement between US and Japan \\
\hline 1921 & Quota Act \\
\hline 1924 & Japanese Exclusion Act \\
\hline 1952 & Immigration and Naturalization Act \\
\hline 1953 & Refugee Relief Act \\
\hline 1965 & Immigration Act \\
\hline 1986 & Immigration Reform and Control \\
\hline 1991 & Immigration Act of 1991 \\
\hline 1996 & Illegal Immigration Act \\
\hline 2001 & USA Patriot Act \\
\hline 2005 & Real Id Act \\
\hline
\end{tabular}

Source: U.S. Immigration and Naturalization Service.

\section{DISCUSSION}

Illegal immigrants do not receive red carpet welcome but they are always welcome by employers since they do not ask for high wages. They do not want any benefits at the end of the day. However, a group of lobbyists always work for keeping the flow of illegal immigration. They retain interests of capitalist groups as illegal immigration benefits US economy (Kane, 1995). Some strongly believe that US economy needs constant flow of illegal immigrants. Immigrants work as unskilled laborers, usually perform jobs which no one perform otherwise (Briggs, 1984). However, with increasing demand from employers, Immigration Reform and Control Act (IRCA) of 1986 allow employers to hire temporary foreign workers. Moreover, employers were given permission to check employees' document, but no power was given them for identifying frauds (Delaet, 2000). American law prohibits an illegal immigrant to seek job at the local markets but there is no restriction on the employer's side to hire an illegal immigrant. This controversial policy impedes the US policy makers to deal with illegal immigration effectively (Briggs, 1984). Even though IRCA come out with restrictive rules for illegal immigration, but immense pressure from liberal groups and courts ruling against IRCA, practically failed to reduce flow of illegal 
immigration and also their living and working in US too.

Historically, both economic and foreign policies have been the key motivating factors for coming up with all rules and laws against illegal immigration, however, Immigration Reform and Control Act 1986 has less impact on both issues. In contrary to popular expectation, even during economic recession, congress failed to pass employer sanctions. Within congressional meetings, foreign policy was never been discussed while implementing any act. Interestingly, State Department expresses concern that with increasing number of laws, diplomatic relationship between Mexico and US is in jeopardy.

In brief, both domestic politics and liberal ideas that exist in the country weaken the power in reducing the flow of illegal immigration. Lack of political motivation, strong liberal opposition, employers' demand, coalition group of ethnic minorities, churches, civil rights organization, make it almost impossible to stop illegal immigration. Bottom line is that even though as a state, USA has strong reasons to reduce illegal immigration, but failed to do so because society as a whole believes in liberal ideas since 1960s (DeLaet, 2000).

\section{CONCLUSION}

Since US has gained economic upsurge, illegal immigration never stops. US has tried implementing all sorts of polices, but still a large number of illegal immigrants managed to sneak into the country. They successfully managed to live in the country. They do not ask for any benefit while they work and stay in the US. This is highly unlikely that US will ever be able to stop flow of illegal immigration. There is an inherent dilemma in the system: main objective of the immigration policy is not to stop illegal immigration rather to control the flow of illegal immigration. Briggs (1984) once commented, "No matter what factors prompt people to leave their homelands and attract them to the United States, and no matter how frequently a review is made of the changes occur in these conditions, the fact remains that the absence of any serious effort to enforce the existing immigration statutes is itself a signal to many persons that the United States really welcomes illegal immigrants, despite the legal pretense that it does not".

A country which is built by immigrants has a little difficulty denying rights of illegal immigrants. If an effective policy which minimizes unauthorized entry can be implemented with the consent of neighboring countries would produce better result in reducing illegal immigration. However, if taking such a policy affects US economy, a cost-benefit analysis is much needed prior to implementing policy. With increasing fear of shrinking population, illegal immigration could be a good source of "future manpower" to maintain sustainable population which eventually would ensure current quality of life. Without having a population policy, this is highly likely that US can deal with illegal immigration. Since US lacks rational population policy, rational immigration policy is a far reaching goal. For a better solution of illegal immigration, a well defined and effective population is much needed.

\section{END NOTES}

U.S. Immigration and Naturalization Service. 1997. 1995 Statistical Yearbook of the Immigration and Naturalization Service. Springfield, VA: National Technical Information Service.

http://archives.gov/exhibits/charters/charters_of_freedom_12.html, accessed on 4th February, 2009.

http://www.uwkc.org/kcca/crosscutting/Immigration/policy.asp, accessed on 4th February, 2009. 


\section{REFERENCES}

Anderas, P. 2000. "Introduction: The Wall after the Wall. In The Wall around the West State Borders and Immigration Controls in North America and Europe. Edited by Peter Andreas and Timothy Snyder. New York: Rowman and Littlefield Publishers, Inc.

Bouvier, Leon F. and Gardner, Robert W. 1986. "Immigration to the U. S.: The Unfinished Story," Population Bulletin 41(4):1-51.

Boyle et al., 1998. Exploring Contemporary Migration. New York: Wesley Longman Limited.

Briggs, Vernon M. 1984. Immigration Policy and the American Labor Force. Baltimore: The Johns Hopkins University Press.

Clark, W. A.V. 1986. Human Migration. Beverly Hills, California: Sage Publications, Inc. Daniels, Roger. and Graham, Ottis L. 2001. Debating American Immigration, 1882-Present. Cumnor Hill, Oxford: Rowman \& Littlefield Publishers, Inc.

DeLaet, Debra L. 2000. U.S. Immigration Policy in an Age of Rights. Conneticut: Prager.

DeSipio, L. and Garza, Rodolfo O. de la. 1998. Making Americans, Remaking America Immigration and Immigrant Policy. Boulder, Colorado: Westview Press.

Kane, H. 1995. The Hour of Departure: Forces that Create Refugees and Migrants. World Watch Paper, 125. Washington, DC: Worldwatch Institute.

Massey, Douglas S. 1999. "International Migration at the Dawn of the Twenty-First Century: The Role of the State", Population and Development Review 25(2): 303-322.

Miller, E Willard. 1996. United States Immigration: A Reference Handbook. Santa Barbara, California: ABC-CLIO, Inc.

Portes, Alejandro. 1991. "Unauthorized Immigration and Immigration Reform: Present Trends and Prospects," Pp. 75-98 in Determinants of Emigration from Mexico, Central America and Caribbean. Edited by Sergio Diaz-Briquets and Sidney Weintraub. Boulder, Co: Westview Press.

Smith, James P. and Edmonston, B. (ed.). 1997. The New Americans Economic, Demographic, and Fiscal Effects of Immigration. Washington, DC: National Academy Press.

Tanton, John H. 1996. "End of the Migration Epoch? Time for a New Paradigm". in Immigration and the Social Contract The Implosion of Western Societies. Edited by Tanton et. al. Brookfiled: Avebury.

Tyler, P. 1956. Immigration and the United States. New York: H. W. Wilson Co. 